TITLE:

\title{
A NEW CHAETOGNATH, EUKROHNIA KITOUI N. SP., FROM THE ENTRANCE TO TOKYO BAY
}

AUTHOR(S):

Kuroda, Kazunori

\section{CITATION:}

Kuroda, Kazunori. A NEW CHAETOGNATH, EUKROHNIA KITOUI N. SP., FROM THE ENTRANCE TO TOKYO BAY. PUBLICATIONS OF THE SETO MARINE BIOLOGICAL LABORATORY 1981, 26(1-3): 177-185

ISSUE DATE:

1981-03-30

URL:

http://hdl.handle.net/2433/176015

RIGHT: 


\title{
A NEW GHAETOGNATH, EUKROHNIA KITOUI N. SP., FROM THE ENTRANGE TO TOKYO BAY ${ }^{12)}$
}

\author{
KAZUNORI KURODA ${ }^{3)}$ \\ Tokai Regional Fisheries Research Laboratory
}

With Text-figures 1-4 and Tables 1-2

\section{Introduction}

Of the 47 specimens of an unknown species of Chaetognatha, the first eleven ones were found in the plankton samples collected by the research vessel "SOYO MARU" of the Tokai Regional Fisheries Research Laboratory around the entrance to Tokyo Bay on Nov. 25, 1977. Detailed examinations made it apparent that the specimens belonged to the genus Eukrohnia. And further comparative studies with the six species of Eukrohnia, regarded as valid, led to the conclusion that the specimens should represent a new species clearly separable from the known six species by its peculiar features.

The anthor wishes to express his deepest appreciation to Dr. T. Tokioka for reading the manuscript and his valuable advice and suggestions and in addition, Dr. K. Furuhashi, Hakodate Marine Observatory, JMA, for his encouragements and kind advice through the course of this study. The author is also very grateful to Dr. A. Alvariño, Southwest Fisheries Center, NOAA, USA, for her useful advice and Dr. M. Terazaki, Otuchi Marine Research Center, Ocean Rescarch Institute, for offering other Eukrohnia samples. The author would like to thank Mr. H. Suzuki and Mr. N. Katakura, Tokai Regional Fisheries Research Laboratory, for offering sampling data and finding present samples. Great thanks are also extended to scientists and crew members of the R.V. SOYO MARU and TAKA MARU for their efforts in collecting plankton samples.

\section{Eukrohnia kitoui sp. nov.}

(Figs. 1 and 2, Tables 1 and 2)

Material: In all 47 specimens were obtained by vertical hauls of Marunaka $\mathrm{A}^{\prime}$ net $(60 \mathrm{~cm}$ in mouth diameter and with mesh of $0.33 \mathrm{~mm})$ made during the re-

1) Contributions from the Seto Marine Biological Laboratory, No. 673.

2) Contribution B No. 693 from the Tokai Regional Fisheries Research Laboratory.

3) Present address: Marine Resources Division, Tokai Regional Fisheries Research Laboratory, 5-5, Kachidoki, Chuo kku, Tokyo 104.

Publ. Seto Mar. Biol. Lab., XXVI(1/3), 177-185, 1981. (Article 10) 
Table 1. Collection records of Eukrohnia kitoui sp. nov.

\begin{tabular}{|c|c|c|c|c|c|c|c|c|}
\hline No. & Station & Location & Date & Time & Depth & $\begin{array}{l}\text { Hauling Layer } \\
\text { Wire Angle }\end{array}$ & $\begin{array}{l}\text { No. of } \\
\text { Speci- } \\
\text { mens }\end{array}$ & Ship \\
\hline 1 & S-10 & $\begin{array}{r}35-04.7 \mathrm{~N} \\
139-43.8 \mathrm{E}\end{array}$ & Nov. 25, 1977 & $12 \mathrm{~h} 45 \mathrm{~m}$ & $180 \mathrm{~m}$ & $150 \rightarrow 0 \mathrm{~m}\left(16^{\circ}\right)$ & 11 & SOYO MARU \\
\hline 2 & S-11 & $\begin{array}{r}35-08.2 \mathrm{~N} \\
139-45.3 \mathrm{E}\end{array}$ & Jan. 20, 1978 & $13 \mathrm{~h} 25 \mathrm{~m}$ & 400 & $150 \rightarrow 0 \quad(9)$ & 4 & SOYO MARU \\
\hline 3 & S- 4 & $\begin{array}{c}35-08.2 \mathrm{~N} \\
139-45\end{array}$ & Feb. 25, 1978 & $09 \mathrm{~h} 35 \mathrm{~m}$ & $400<$ & $150 \rightarrow 0 \quad(25)$ & 2 & TAKA MARU \\
\hline 4 & $S-11$ & $\begin{array}{r}35-08.2 \mathrm{~N} \\
139-47.8 \mathrm{E}\end{array}$ & Mar. 19,1978 & $14 \mathrm{~h} 40 \mathrm{~m}$ & 185 & $150 \rightarrow 0 \quad(38)$ & 16 & SOYO MARU \\
\hline 5 & S-13 & $\begin{array}{r}35-06.3 \mathrm{~N} \\
139-48.3 \mathrm{E}\end{array}$ & Mar. 19, 1978 & $15 \mathrm{~h} 10 \mathrm{~m}$ & 270 & $150 \rightarrow 0 \quad(26)$ & 4 & SOYO MARU \\
\hline 6 & S-14 & $\begin{array}{r}35-02.2 \mathrm{~N} \\
139-47.4 \mathrm{E}\end{array}$ & Mar. 19, 1978 & $15 \mathrm{~h} 55 \mathrm{~m}$ & 80 & $75 \rightarrow 0 \quad(19)$ & 1 & SOYO MARU \\
\hline 7 & S-11 & $\begin{array}{rl}35-05 & \mathrm{~N} \\
139-41 & \mathrm{E}\end{array}$ & Mar. 27, 1978 & $15 \mathrm{~h} 40 \mathrm{~m}$ & 210 & $150 \rightarrow 0 \quad(21)$ & 1 & TAKA MARU \\
\hline 8 & S-11 & $\begin{array}{r}35-08.2 \mathrm{~N} \\
139-45.9 \mathrm{E}\end{array}$ & Nov. 29, 1978 & $18 \mathrm{~h} 12 \mathrm{~m}$ & 410 & $400 \rightarrow 0 \quad(22)$ & 8 & SOYO MARU \\
\hline
\end{tabular}

search cruises of R.V. SOYO MARU and TAKA MARU of the Tokai Regional Fisheries Research Laboratory (Table 1). Of these, only 30 specimens found in a good state of preservation were measured and examined for the present description.

Holotype: NSMT-Ch 1. $24.0 \mathrm{~mm}$ long, obtained by a vertical haul from $400 \mathrm{~m}$ to surface at Stn. S-11 $\left(35^{\circ}-08^{\prime} \mathrm{N}, 139^{\circ}-46^{\prime} \mathrm{E}\right)$ on Nov. 29, 1978; deposited in the National Science Museum, Tokyo.

Paratype: NSMT-Ch 2. A series of 29 specimens in a good state of preservation, deposited together with the holotype.

Description: A medium-sized species. The 30 specimens studied range from 7.9 to $24.5 \mathrm{~mm}$ in body length without tail fin. The body is firm, opaque, widest in the posterior part of the trunk around the level of the anterior part of ovaries;

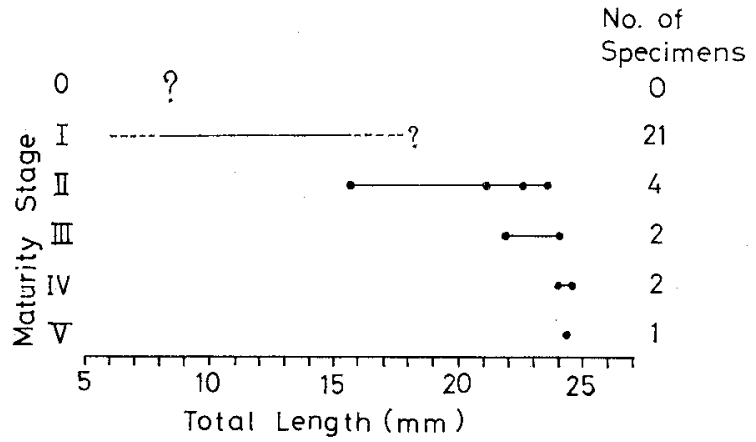

Fig. 1. Total length and maturity stages of Eukrohnia kitoui sp. nov. 
the constriction at the tail septum is insignificant. The head is large and the neck is very conspicuous. No collarette is found. The lateral fins are long, anteriorly a little ahead the top of the ventral ganglion and posteriorly to the posterior part of the tail segment, and widest approximately at the middle of the tail segment. They are the same shape as the other Eukrohnia species and easily curled up and damadged. The posterior part to the tail septum of the fin is furnished with fin rays thoroughly. The tail segment constitutes 20 to $26 \%$ of the body length of the animal. The tail

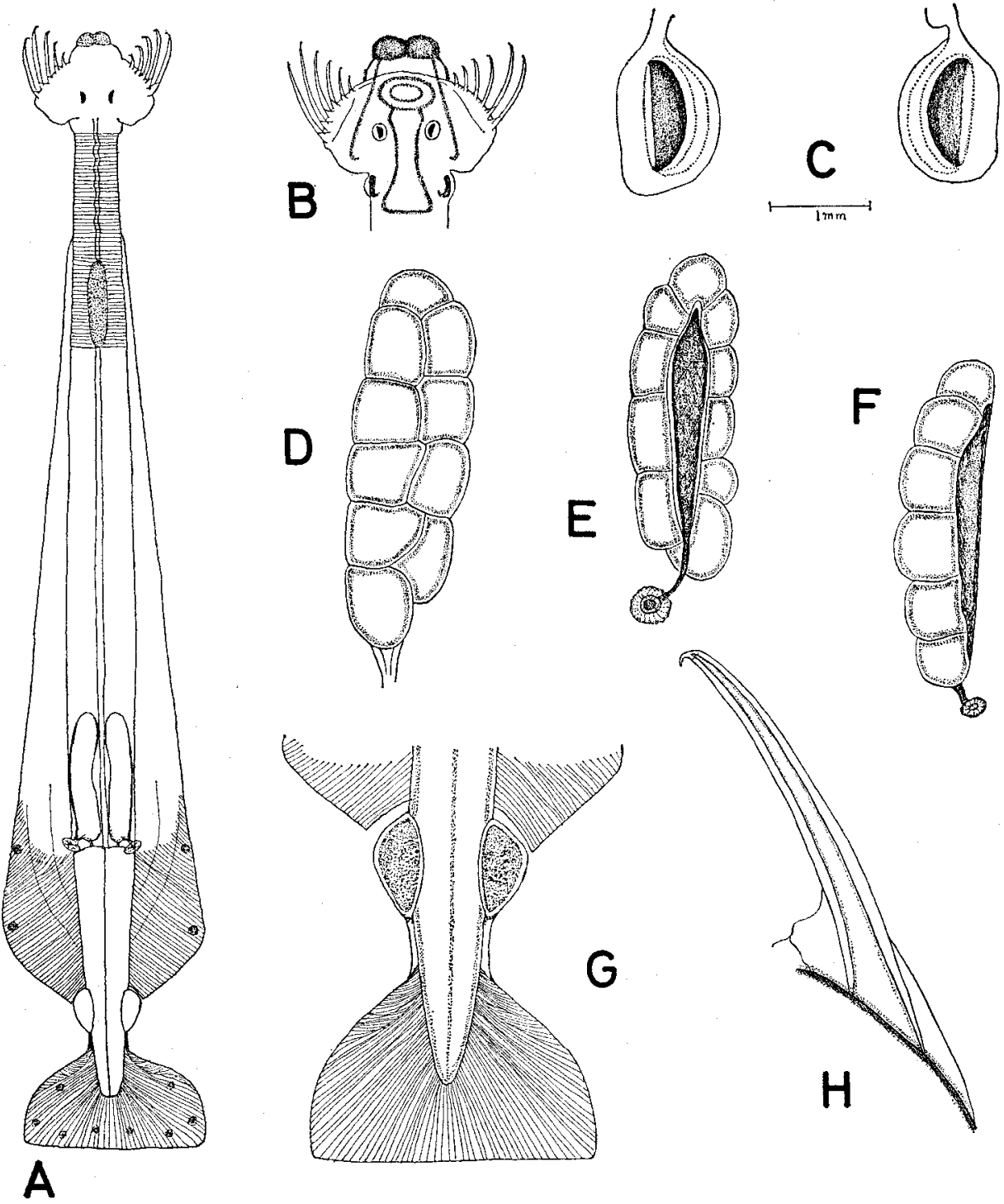

Fig. 2. Eukrohnia kitoui sp. nov.

A, Dorsal side; B, Head and neck, dorsal side; C, A pair of eyes; D-F, Ovary, internal (D), external (F), and dorsal (F) side; G, Posterior part of tail, dorsal side; $H$, A hook from right side. 
fin is somewhat broad triangular. On both the body and fins many distinct sensory spots are arranged regularly. The two specimens larger than $24 \mathrm{~mm}$ are fully mature and seemingly in the IV or V stages according to the Thomson's Mature Basis. No specimen of the 0-stage without any trace of ovaries has been found (Fig. 1).

An extremely prominent glandular reservoir is found at the top of the head; it is seemingly constituted of two parts. The eyes are large and arranged as " $V$ ". The eye pigments are black-brown and look semielliptical in outline, though the pigments themselves are distributed to form a bowl-like configuration. The hooks are 8 to 9 on each side in the specimans of 8 to $16 \mathrm{~mm}$ in body length, while 12 to 13 in those of 21 to $25 \mathrm{~mm}$. They are almost straight and with the tip sharply bent; no serration is found on them in any specimens. Anterior teeth are absent. The posterior teeth are 10 to 16 on each side in the specimens studied, though it is rather difficult to observe these weak teeth under the microscope.

The corona ciliata is elongated flask-shaped, extending posteriorly on to the neck region. A pair of short gland canals are present on each side of the neck region.

Table 2. Specific characteristics

\begin{tabular}{|c|c|c|c|}
\hline Character & E. namata & E. fowleri & E. bathyantarctica \\
\hline Total length (mm) & 43 & 40 & 31 \\
\hline Tail segment $(\%)$ & $19-24$ & $22-25$ & $19.3-25$ \\
\hline $\begin{array}{l}\text { Eyes } \\
\quad \text { (arrangement) } \\
\quad \text { (ommatidia) }\end{array}$ & $\begin{array}{c}\text { No pigment } \\
" \wedge " \text {-shaped } \\
80-100 \text {, in } 3 \text { to } 4 \text { rows }\end{array}$ & $\begin{array}{c}\text { Pigmented, small } \\
\qquad \wedge " \text {-shaped } \\
?\end{array}$ & $\begin{array}{c}\text { No pigment } \\
\text { "八"-shaped } \\
?\end{array}$ \\
\hline Corona ciliata & Flask-shaped & Pear-shaped & Unknown \\
\hline $\begin{array}{l}\text { Hooks } \\
\qquad \begin{array}{l}\text { (shape) } \\
\text { (serration) }\end{array}\end{array}$ & $\begin{array}{l}\quad 8-9(10) \\
\text { Straight, point end } \\
\text { gently curved } \\
\text { Present }\end{array}$ & $\begin{array}{l}10-13 \\
\text { Gently curved } \\
\text { Present }\end{array}$ & $\begin{array}{c}<14 \\
\text { Gently curved } \\
?\end{array}$ \\
\hline Posterior teeth & $<23-25$ & $<30$ & $<16$ \\
\hline Lateral fins & $\begin{array}{l}\text { From level of ventral } \\
\text { ganglion to seminal vesi- } \\
\text { cles, with rays in posterior } \\
\text { part }\end{array}$ & $\begin{array}{l}\text { From level of anterior } \\
\text { part of ventral ganglion } \\
\text { to seminal vesicles, with } \\
\text { rays only at the posterior } \\
\text { part opposite to tail } \\
\text { segment }\end{array}$ & $\begin{array}{l}\text { From level of ventral } \\
\text { ganglion to the middle } \\
\text { on tail segment }\end{array}$ \\
\hline Collarette & $\begin{array}{l}\text { Absent, only a layer at } \\
\text { base of tail fin }\end{array}$ & $\begin{array}{l}\text { Present, around ventral } \\
\text { ganglion and extending } \\
\text { to openings of oviducts }\end{array}$ & Absent \\
\hline Ovaries & $\begin{array}{l}\text { Up to the middle on } \\
\text { trunk, small ova in four } \\
\text { rows }\end{array}$ & $\begin{array}{l}\text { Short, with a few large } \\
\text { ova in two rows, open- } \\
\text { ings of seminal receptacle } \\
\text { as a sort of capsule }\end{array}$ & Short; ova in two rows \\
\hline Seminal vesicles & Elongated ovoid & $\begin{array}{l}\text { Ovoid, separated from } \\
\text { tail fin }\end{array}$ & $\begin{array}{l}\text { Ovoid, separated from } \\
\text { tail fin }\end{array}$ \\
\hline
\end{tabular}


The ventral transverse musculature is extending from the neck to the posteroir edge of the ventral ganglion. No intestinal diverticula are observed. In some specimens, the material like dark-greyish oil droplets was found near the posterior part of the intestine. The ovaries are short, $3.3 \mathrm{~mm}$ long in mature state and occupying about $13.5 \%$ of the body length. There are 10-13. large and round ova in mature specimens and arranged in two, dorsal and ventral, rows. Maximum ova are about $0.5 \times 0.6-0.7 \mathrm{~mm}$ in diameter. The seminal vesicles are clearly ovoid, and anteriorly almost touching the posterior end of the lateral fin and posteriorly separating just from the tail fin.

Remarks: The features described above show clearly that the present specimens belong to the genus Eukrohnia that is defined mainly on the following characters: The lateral fin extending from the trunk to the tail, the ventral transverse musculature in the anterior part of the trunk, a row of posterior teeth on each side of the head, but missing the anterior teeth, a pair of lateral gland canals in the neck region, the glandular reservoir at the top of the head, and wholly absent of the in-

of the 7 species of Eukrohnia.

\begin{tabular}{|c|c|c|c|}
\hline E. bathypelagica & E. proboscidea & E. minuta & E. kitoui sp. nov. \\
\hline 23 & 25 & 21 & 24.5 \\
\hline $25.8-34$ & $21-31$ & $27-35$ & $22-24$ \\
\hline $\begin{array}{c}\text { No pigment } \\
\text { " } " \text { "shaped } \\
\text { More than } 100,5 \text { to } 6 \text { rows }\end{array}$ & $\begin{array}{c}\text { Pigmented, slender } \\
" ハ \text { "shaped } \\
\text { Absent }\end{array}$ & $\begin{array}{l}\text { No pigment } \\
\text { “ハ"-shaped } \\
\text { About } 20\end{array}$ & $\begin{array}{c}\text { Pigmented, large and } \\
\text { semicircular, " } y " \text { "shaped } \\
\text { Absent }\end{array}$ \\
\hline Unknown & Unknown & Unknown & Elongated flask-shaped \\
\hline $\begin{array}{l}\qquad 7-10(9) \\
\text { Straight, point end gent- } \\
\text { ly curved }\end{array}$ & $\begin{array}{l}10-13 \\
\text { Straight, point end } \\
\text { gently curved } \\
\text { ? }\end{array}$ & $\begin{array}{l}\text { Straight } \\
\text { Present }\end{array}$ & $\begin{array}{l}\quad 8-13 \\
\text { Straight, point end sharp- } \\
\text { ly bent } \\
\text { Absent }\end{array}$ \\
\hline $17-22$ & $12-25$ & $8-14$ & $10-16$ \\
\hline $\begin{array}{l}\text { From level of ventral } \\
\text { ganglion to seminal } \\
\text { vesicles, broad and bent } \\
\text { dorsally at posterior } \\
\text { rayed end }\end{array}$ & $\begin{array}{l}\text { From level of an- } \\
\text { terior part of ven- } \\
\text { tral ganglion to } \\
\text { the middle on tail } \\
\text { segment }\end{array}$ & $\begin{array}{l}\text { From level of posterior } \\
\text { on-third of ventral gang- } \\
\text { lion to seminal vesicles, } \\
\text { with rays in posterior } \\
\text { part }\end{array}$ & $\begin{array}{l}\text { From level of anterior } \\
\text { part of ventral ganglion } \\
\text { to seminal vesicles, with } \\
\text { rays in posterior part }\end{array}$ \\
\hline $\begin{array}{l}\text { Present, around ventral } \\
\text { ganglion to seminal } \\
\text { vesicles, broader at open- } \\
\text { ings of oviducts }\end{array}$ & Absent & $\begin{array}{l}\text { Absent, only a thin layer } \\
\text { on tail segment and } \\
\text { small one at base of tail } \\
\text { fin }\end{array}$ & Absent \\
\hline $\begin{array}{l}\text { Up to midway from neck } \\
\text { to tail septum, filling } \\
\text { body cavity; large ova } \\
\text { in two rows, coiling in } \\
\text { immature state }\end{array}$ & $\begin{array}{l}\text { Short; ova in two } \\
\text { rows }\end{array}$ & $\begin{array}{l}\text { Short; ova in only a } \\
\text { single row }\end{array}$ & $\begin{array}{l}\text { Short, with large ova in } \\
\text { two rows; openings of } \\
\text { seminal receptacle as sort } \\
\text { of capsule }\end{array}$ \\
\hline $\begin{array}{l}\text { Ovoid, separated from } \\
\text { tail fin }\end{array}$ & $\begin{array}{l}\text { Ovoid, separated } \\
\text { from tail fin }\end{array}$ & $\begin{array}{l}\text { Ovoid, separated from } \\
\text { tail fin }\end{array}$ & $\begin{array}{l}\text { Ovoid, separated from } \\
\text { tail fin }\end{array}$ \\
\hline
\end{tabular}


testinal diverticula (Tokioka; 1940, 1965).

The present specimens may easily be distinguishable from any known species of Eukrohnia at a glance: for example, by their markedly prominent glandular reservoir at the top of the head, the presence of large eye pigments, and the starting position of the lateral fins. However, for further detailed comparison, the specific characters of the 6 recognized species of Eukrohnia are given, together with those of the present specimens in Table 2. While the characters of Eukrohnia hamata (Möbius), 1875, E. forvleri Ritter-Záhony, 1909, E. bathyantarctica David, 1958, and E. bathypelagica Alvariño, 1962 came mainly from the table given by Alvariño (1967), those of both $E$. proboscidea and $E$. minuta were picked up from the original papers respectivly by Furnestin and Ducret (1965), and Silas and Srinivasan (1969).

The structure and the arrangement of the eyes and the shape of the eye pigments are very important signs for rapid identification of Chaetognatha (Tokioka, 1940; Nagasawa and Marumo, 1976). In the present specimens, it is really unique that the eyes are arranged as " $\vee "$, while they are arranged as " $ハ$ " or in parallel in all the known species of Eukrohnia. The eyes are pigmented in the present specimens as well as in $E$. fowleri and E. proboscidea. In E. fowleri, however, the eye pigments are very small and found in the ommatidia. Both the present specimens and $E$. proboscidea are provided with large eye pigments, but the detailed comparison of the eye pigments seems impossible between these two species for insufficient description in the latter; it was only stated that the eye pigments are slender and brown in E. proboscidea. The glandular reservoir is prominent in E. proboscidea as well as in the present specimens. The maximum body length is also similar between $E$. proboscidea and the present specimens. Thus, it is evident that the present specimens are related most closely to $E$. proboscidea.

However, the present specimens are clearly separable from $E$. proboscidea by, in addition to the arrangement of eyes, the number of the posterior teeth at respective body length. According to Furnestin and Ducret (1965), the posterior teeth are 12-14 in E. proboscidea at the body length of $15.3 \mathrm{~mm}$ but increase to $23-25$ at $25 \mathrm{~mm}$. In the present specimens, there are 10-11 teeth in $12.7 \mathrm{~mm}$ long individual and about 15-16 ones in the individuals larger than $21 \mathrm{~mm}$. So to speak, the increase of the posterior teeth is significantly less in the present specimens than $E$. proboscidea. Although the number of hooks can be specific, it varies with growth, too; therefore this is unavailable to distinguish the present specimens from other species of Eukrohnia, till the relation between the number of hooks and the body length is fully cleared up in any species of the genus. Only the present specimens may be distinguished from other species by that the hooks are bent sharply almost at a right angle at the top. As the shape of seminal vesicles is, generally speaking, elongated ovoid in the 7 present species of Eukrohnia, it is not proper as a key character to identify in species rank. All these comparisons made above seem to justify the establishment of a new species for these specimens, and here is proposed the specific name kitoui.

Etymology: The new species is dedicated to the late Dr. Masataka Kitou (1929 1975), who was engaged in planktological and oceanographical investigations for 


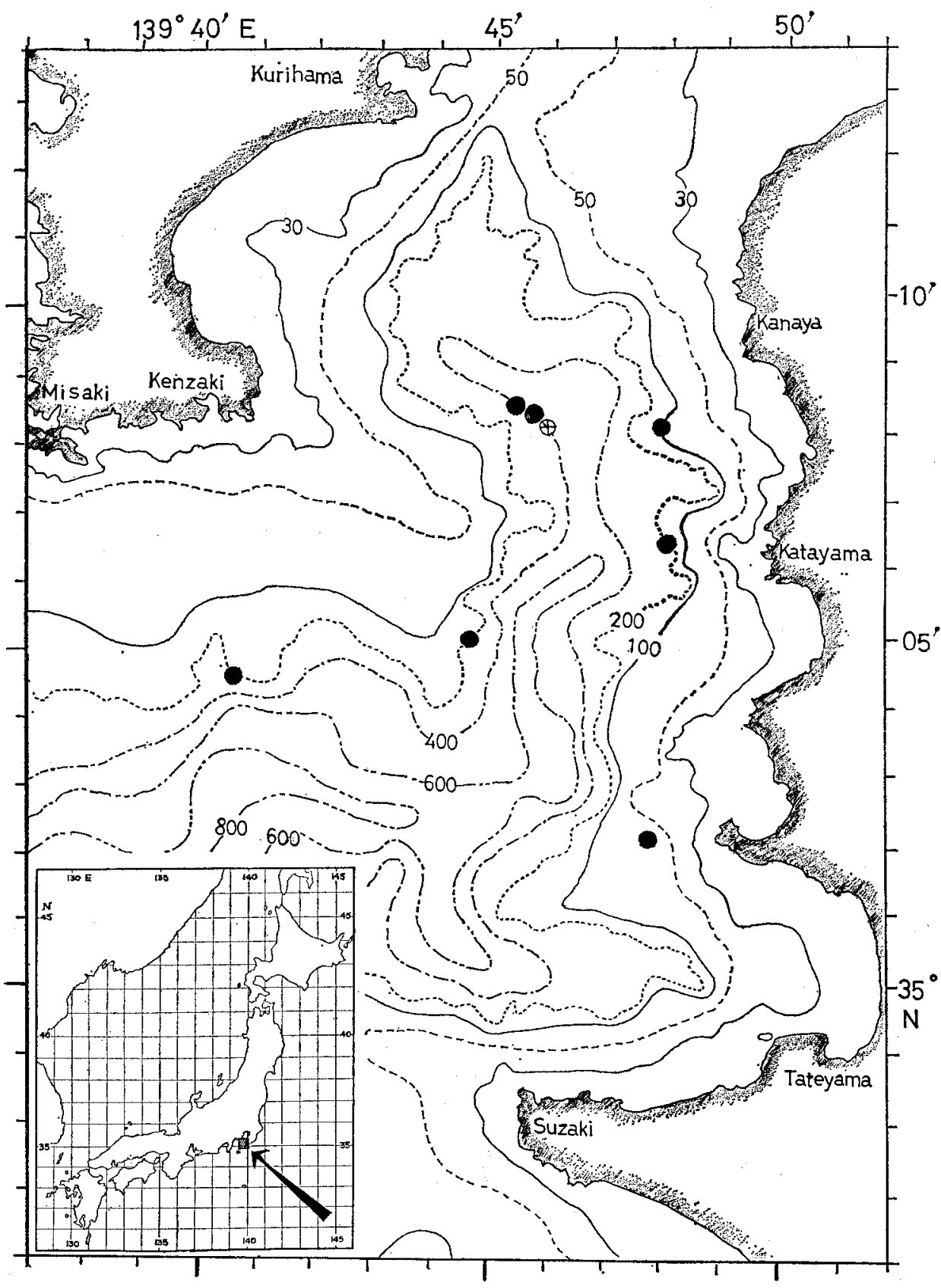

Fig. 3. Occurrences of Eukrohnia kitoui sp. nov, around the entrance to Tokyo Bay. : 0-150 m haul, $\oplus: 0-400 \mathrm{~m}$ haul. 
a long time in the Japan Meteorological Agency and left a number of contributions to the study of marine zooplankton, especially the Chaetognatha.

\section{Distribution}

Although Murakami (1957) recorded 3 genera and 16 species of chaetognaths in Tokyo Bay and Nagasawa and Marumo (1977) obtained 3 genera and 17 species inclusive of 1 form of chaetognaths from the surface layer of Sagami Bay, they could not find the present new species in their materials. Really, the present new species occurred in only 7 of 95 vertical hauls of Marunaka $A^{\prime}$ net from $150 \mathrm{~m}$ to surface around the entrance to Tokyo Bay. This shows evidently that the new species is rarely distributed in the surface layer above $150 \mathrm{~m}$ and its domain might be found in the layer below $200 \mathrm{~m}$ on the continental slope and its submarine canyon around the entrance to Tokyo Bay (Fig. 3). Nevertheless, Marumo and Nagasawa (1973) could not find this new species throughout some collections of meso- and bathypelagic chaetognaths obtained in both Suruga and Sagami Bays. This might suggest that the distribution of the present new species can be extremely limited.

From the T-S diagram at the stations where the new species was collected, the range of occurrences of the new species may be characterized at present by the water temperature from 10 to $15^{\circ} \mathrm{C}$, the salinity from 34.42 to $34.57 \%$ and the in situ density from 25.5 to 26.5 (Fig. 4). All these data are, however, too poor to present any conclusion as to the distribution of this new species. Futher researches will be looked forward to clear up the real domain of this new species.

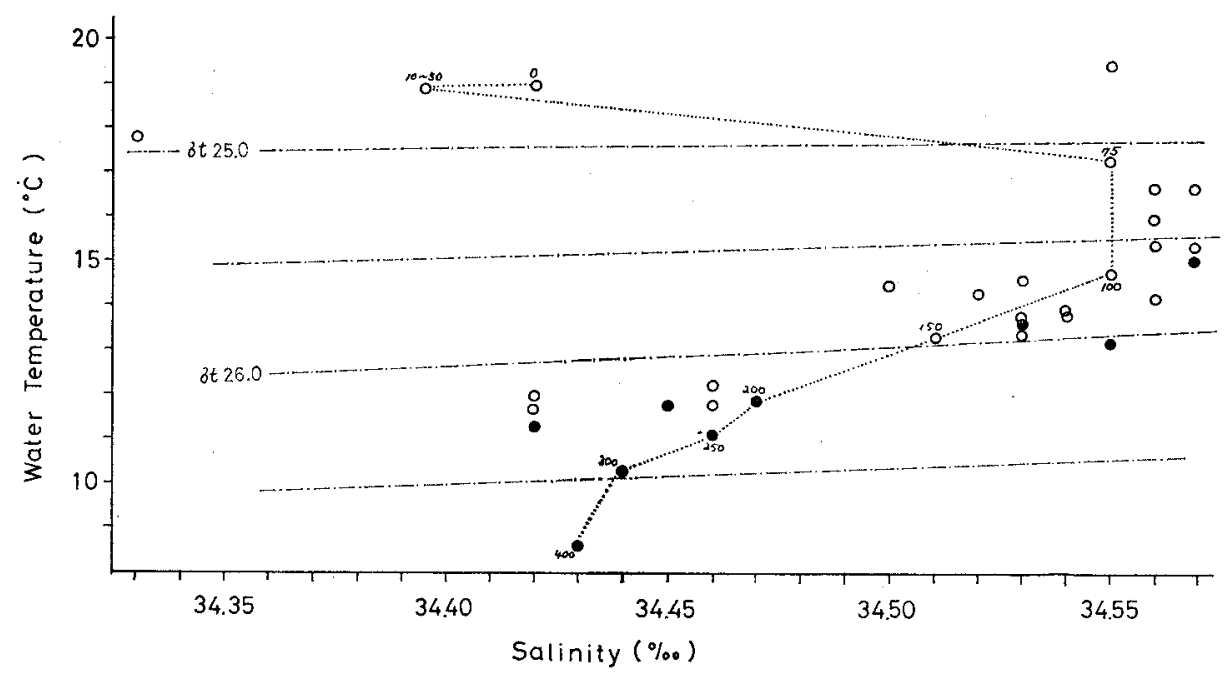

Fig. 4. Temperature-salinity relation at $150 \mathrm{~m}$ layer at surveyed stations. : stations where Eukrohnia kitoui was obtained. $\bigcirc$ : staitions where $E$. kitoui was not collected. A series of marks chained are the T-S relations from the surface to $400 \mathrm{~m}$ observed at Stn. S-11 on Nov. 29, 1978. 


\section{LITERATURE}

Alvariño, A. 1962. Two new Pacific chaetognaths; their distribution and relationship to allied species. Bull. Scripps Inst. Oceanogr., 8 (1), 1-50.

Alvariño, A. 1967. The Chaetognatha of the NAGA Expedition (1959-1961) in the South China Sea and the Gulf of Thailand. I. Systematics. NAGA Rep. Univ. Calif. Scripps Inst. Oceanogr., 4, 1-197.

David, P.M. 1958. A new species of Eukrohnia from the Southern Ocean with a note on fertilization. Proc. Zool. Soc. London, 131 (4), 597-606.

Furnestin, M.L. and F. Ducret 1965. Eukrohnia proboscidea, nouvelle espèce de Chaetognathe. Rev. Trav. Inst. Pêches marit., 29 (3), 271-273.

Marumo, R. and Nagasawa 1973. Pelagic chaetognaths in Sagami Bay and Suruga Bay, central Japan. Jour. Oceanogr. Soc. Japan, 29 (6), 41-49.

Murakami, A. 1957. The occurrence of planktonic chaetognaths in the bay and Inland Sea regions. (I) On the occurring conditions in Tokyo Bay, and the central and western parts of Seto Inland Sea. Suisangaku-Syusei, pp. 357-384. Tokyo. (in Japanese)

Nagasawa, S. and R. Marumo 1976. Identification of young chaetognaths based on the characteristics of eyes and pigmented regions. Bull. Plankton Soc. Japan, 32 (2), 46-52. (in Japanese)

Nagasawa, S. and R. Marumo 1977. Seasonal variation in composition and number of epipelagic chaetognaths in Sagami Bay, Japan. La mer, 15 (4), 185-195. (in Japanese)

Silas, E.G. and M. Srinivasan 1969. A new species of Eukrohnia from the Indian Sea with notes on three other species of Chaetognatha. Jour. Mar. Biol. Asso. India, 10 (1), 1-33.

Tokioka, T. 1940. Phylum Chaetognatha. Fauna Nipponica, 5 (2), pp. 1-129. Sanseido, Tokyo. (in Japanese)

Tokioka, T. 1965. Phylum: Chaetognatha. Animal Genealogy, 8, pp. 259-292. Nakayama Shoten, Tokyo. (in Japanese) 